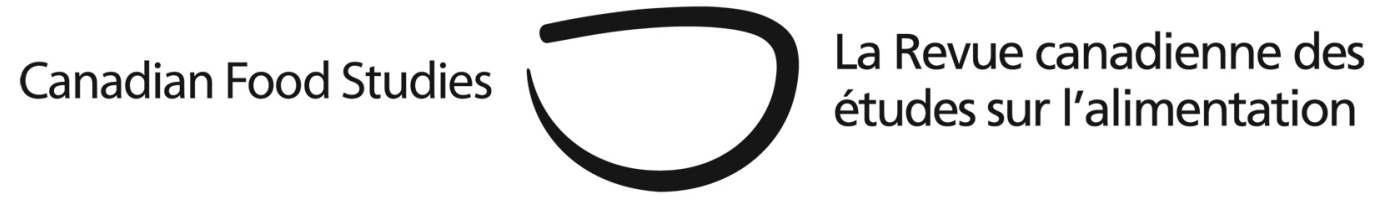

Perspective

\title{
Life of Bryan: Working the magic of sustainable food's sweet spot
}

\section{Part Two}

Wayne Roberts ${ }^{1}$

\begin{abstract}
Bryan Gilvesy is one of Canada's most recognized farm innovators, as well as one of the country's best-known leaders of the food movement. That combination is unusual in any region or country - one of the ways that Gilvesy exemplifies both the hallmarks of the food movement in Canada, as well as the unique components of agro-ecology as it emerges in a temperate-cold climate. This portrait of a food and farm leader is based on my own reporter's notes taken over seven years of attending meetings where Gilvesy has spoken, and on files of news clippings and academic articles related to the farming methods he has pioneered in Canada. Part One of this article provided an overview of Gilvesy's background and personal evolution prior to his adoption of views and practices for which he is currently renowned. Part Two introduces his measures to secure a wrenching shift in food system redesign-specifically the provision to pay farmers for ecosystem services they produce on the working landscape of their farm. Part Two will also spell out specific trends within Canada's food movement, such as its promotion of concrete, positive and practical reform measures and its service as a Big Tent coalition of various

\footnotetext{
${ }^{1}$ Wayne Roberts is internationally recognized as a leading analyst, advocate, and practitioner in the field of city food policy. From his home base in Toronto, Dr. Roberts has written 12 books, most recently The No Nonsense Guide to World Food ( $2^{\text {nd }}$ Edition) and Food for City Building. He is also a longtime associate of Bryan Gilvesy, and has volunteered for two years as an unpaid "director of sustainability education" for Y U Ranch, which Gilvesy owns.
} 
public interest groups - trends that Gilvesy personifies. Part Three will examine the potential of establishing a fee for environmental services through public policy rather than the marketplace.

\section{Part Two}

In Part One of this article in the premier issue of the CAFS journal, readers learned about the early career of Bryan Gilvesy, winner of many awards for his innovative farming methods as well as a prominent leader of and speaker for the food movement, especially in Ontario. He began his career as a tobacco farmer, but left that behind in the 1990s when he turned to breeding and raising Texas Longhorns for beef. When mad cow disease struck the Canadian beef industry in 2003, Gilvesy was in a position where he could sell his beef because he had kept his herd totally free of the feeds that produced mad cow, and from the cattle that carried it. He became a solo entrepreneur, free of the conventional food chain, selling directly to his own customers-a position that brought him to ever-more profound understandings of the strategies and benefits of sustainable production methods, and the need to partner with a varied group of people in what was becoming the food movement. Part Two carries on from this point.

The next big change in Gilvesy's life came in 2005. His inner business grad told him there had to be a more objective and certifiable way to define where the value of his product came from, over and above the trust he enjoyed from customers who knew him personally. The penny dropped in December 2005 when he heard Brian Abel-a nearby farmer and chair of the Norfolk County Stewardship Council—speaking about a fledgling program called Alternative Land Use Services (ALUS), which had just launched in Manitoba. Gilvesy liked the ALUS message about farmers working to proactively avoid inflicting damage on the environmentrather than simply mitigating the damage after-the-fact, through what was called "risk management." At the meeting, Gilvesy asked Abel for his advice about protecting the stream that went through his property. The next day, Abel arranged an introduction to Dave Reid, a Norfolk Stewardship Coordinator with the Ministry of Natural Resources. Reid toured Gilvesy’s farm, praised him for fencing his woods and stream - to keep the cattle from doing damage_and explained that ALUS offered a way for a good steward like him to be paid for his good work. By the spring of 2006, Y U Ranch was a demonstration farm for ALUS. "I got out of the food business, and got into the business of nourishment," Gilvesy says. In his words, he found the "sweet spot"-where what is good for farmer and consumer and environment are the same. As he put it to a group of potential ALUS supporters in Alberta seven years later: "Instead of just harvesting one crop from your farm or property, harvest a whole bunch, let's harvest more environment, better food. Let's harvest health."2

ALUS gave Gilvesy the tools to see his entire farm in a different light. Many people think of forests and marshes as being ecologically fragile and/or valuable, but relatively few think the grasslands in between have much value. Given that grasslands cover 3.5 billion hectares, about a

\footnotetext{
${ }^{2}$ Clarkson, M. (2013, June 20). Vermilion River County receives wetland agency recognition. Lloydminster Source.
} 
third of the land on the planet, this landscape is worth a second look. Only about two percent of the original wild grasses and tall grass prairie in North America at the time of European conquest still exist today, and few voices are raised to stem the loss. Tall grass is rarely deemed worthy of protection in parks, which means that most of it is on farms, where farmers are liable to see it as taking up space that could go to grain crops that make money. Though tall grass ecosystems lack the charisma of grizzlies and elk, and tall grass is not a cash crop in the way grains are, naturalists who like to watch birds — and hunters who like to eat them — understand that these tall grasses hide grassland birds from predating eagles and hawks, while they nest, give birth, and raise their young. Just as Ducks Unlimited arose to allow duck hunters to pay farmers to protect the forest and marsh habitat of ducks on their land, so ALUS arose to connect hunters and bird watchers to the protection of grassland birds. ${ }^{3}$

ALUS recognized that both the public and private should benefit from preserving grassland. Since Nature doesn't donate money to conscientious farmers, and since no environmental bonus is included in the price of food, marginal land-less productive and more ecologically fragile - only has economic value if converted into farmland for cash crops. ALUS recognized that farmers deserve a thank you if they voluntarily give up the possibility of growing crops on that marginal farmland, and instead conserve it for the benefit of Nature and the general public. ALUS asked members of the public who most benefitted from a farmer's actions to recognize and reward that unpaid contribution by chipping in with a donation.

The common sense of ALUS sounds so obvious that readers might miss the clanging of bells and whistles that usually goes with a revolutionary insight. In the ALUS analysis, Nature and diversity are to be respected and valued not only when they provide resources that can be converted directly into inputs for food and sold for money, but also when they provide services to Nature and the general public — both of which benefit from the conservation of diversity in historic grasslands habitat. ALUS asks farmers to give of their time and their privately held resources to restore natural vegetative cover and let their land lie "idle"-from a short-term money-making perspective. In exchange, ALUS asks that direct and identifiable beneficiaries of wild grasslands, such as hunters and bird watchers, donate a modest fee to cover a farmer's expenses and time.

ALUS stepped in to facilitate this transaction because government overseers of the food system have a massive blind spot for Nature's contribution of services that make agriculture viable. The mindset of industrial agriculture is so mechanistic, and so obsessed with overcoming natural limits, that the enabling role of Nature-and the need to sustain that enabling rolecomes as a surprise and afterthought at best. ALUS also challenges the power of the food system taboo against paying farmers for anything but the commodity value of food, fiber, fuel or tobacco - all of which are self-evident products of human labor and machines and a tribute to having overcome, not protected, Nature. Such worldviews explain the difficulty experienced by government officials across North America in grasping the basic insight of ALUS: the need to actively support-i.e., pay for-delivery of Nature’s services.

\footnotetext{
${ }^{3}$ Terborgh, J. (2007, April 26). Hero of Birdland. New York Review of Books.
} 
Odd as it seems, most governments can see their way to support or subsidize farmers to grow corn on former grasslands - oftentimes corn that goes to ethically, nutritionally, and ecologically negative purposes, such as feed for livestock in factory farms, cheap substitutes for sugar in soft drinks and other junk foods, and corn ethanol substitutes for petroleum in automobile gas tanks. To make matters worse, corn is also extremely harsh on farmland, especially on fragile land vulnerable to erosion. But no one in government-which ostensibly has a mandate to oversee the public interest in food and farming — can see a way to pay farmers to grow more health-supporting food, let alone manage grasslands, woodlots, or marshes, or otherwise help Nature recover its original resilience and robustness. That would be tantamount, I suppose, to a subsidy for Nature's idleness, and would set a bad precedent for supporting the idleness of the poor with adequate income to buy local, sustainable, and nutritious foodsanother taboo. The neurotic fear of food-system change seems to be so powerful that governments will subsidize corn farmers to grow a surplus of badly used product, and thereby produce such a glut of corn that the price is always threatening to collapse, creating a treadmill that leads the industry to find ever more ways to incorporate corn into more junk foods, car fuels, or plastic. Go figure.

\section{Splendor in the grass}

Since 2006, Gilvesy has converted his entire farm—save areas covered by woodlands, streams, and marshlands - over to grasslands. At the time he started this, people might have thought his project was for the birds. But emerging research findings show that the environmental productivity of grasslands goes much further than providing habitat for birds. It's about bees, too, and other threatened pollinators that make fruits and vegetables bountiful. It's also about global warming - the 900-pound gorilla that no government can manage, but which grasslands can do something about. In all, the environmental services from grasslands have the potential to become life savers for humans and others. With the evidence now available and easily accessible by government staff, government failure to support farmers who convert fragile farmlands back to historic grasslands constitutes neglect of duties to due diligence and care, which future generations may well judge to be criminally irresponsible. Put me in touch with a lawyer, and let's find out if the charge sticks.

A highly credible set of studies—-from Marin County, California—suggests that grasslands provide valuable services to address global warming. Berkeley ecology professor Whendee Silver and her colleagues have been conducting studies on Marin County ranches for five years. ${ }^{4}$ They spread half an inch of compost over fields of grass, and proved that this

\footnotetext{
${ }^{4}$ Johnson, N. (2014). Just add compost: How to turn your grassland ranch into a carbon sink. Grist. Also see www.marincarbonproject.org; Silver, W., DeLonge, M.S. \& Owen, J.J. (2013). Climate Change Mitigation Potential of California’s Rangeland Ecosystems, a draft report to the California Air Resources Board; DeLonge, M.S., Ryals, R. \& Silver, W. (2013). A lifecycle model to evaluate carbon sequestration potential and greenhouse gas dynamics of managed grasslands. Ecosystems, 16: 962-979.
} 
treatment led to a fifty percent increase in plant growth, thereby adding an additional metric tonne of carbon to each hectare of soil. If not used on the fields to support carbon storage, the compost would have ended its days in landfill, rotting away without access to oxygen, thereby creating methane- - twenty-two times more powerful than carbon dioxide when it comes to global warming impact. Anyone worried that cattle munching on grasslands also produce methane by burping and farting has to take into account that grasslands can make ready use of compost that would otherwise create much more methane than burping and farting by cattle. The additional growth of grass on composted fields also removes the need of ranchers to buy commercial grains from other farms, thereby avoiding the global warming emissions from fertilizers, pesticides, and harvesting equipment used to produce grains.

The cattle on these lands make up for their vulgar farting and burping by delivering a number of ecoservices. Their constant nibbling keeps grasses short, thereby reducing the likelihood of wildfires, which release enormous amounts of carbon into the air. If such an approach to grasslands were applied to half the rangeland in California, according to Silver, it would offset the equivalent of forty-two million metric tonnes of carbon dioxide-equal to the yearly emissions from commercial and residential fossil fuel energy use by all Californians. This kind of potential impact invites public action, and it is up to the food movement to hold government feet to the fire by framing these proposals as part of a package of urgent solutions that need to be taken up for many reasons. Can you spell multifunctional agriculture?

Beyond global warming impacts, the broad ecological importance of properly managed livestock grazing on grasslands is confirmed by several studies and reports, including an Ontario Ministry of Agriculture fact sheet, which credits grasslands with reducing erosion by as much as ninety-three percent. ${ }^{5}$ Several scientific studies credit the combination of livestock grazing and grasslands with reducing pesticide use, speeding up the recycling of manure, and increasing biodiversity. ${ }^{6}$ Joshua Farley, with a keener sense of public policy advocacy than most scientists linked to agricultural and land use studies, lists the benefits of "management-intensive grazing" (MIG). “Compared to conventional systems, MIG increases pasture growth and cattle production, reduces the use of fertilizers and pesticides, and enhances biodiversity, water quality, nutrient capture, and carbon sequestration." ${ }^{7}$ Farley argues that payments for such environmental services "are a promising mechanism through which those who benefit from ecosystem services can compensate those who provide them, for mutual gain." ${ }^{8} \mathrm{He}$ and his colleagues propose that public beneficiaries of ecosystem services must find ways to transfer resources from beneficiaries to providers at the local, national, and global scales, to support the research, education, training, and easy access to low-cost credit by farmers to get such projects moving.

\footnotetext{
${ }^{5}$ Ontario Ministry of Agriculture and Food, Environmental Farm Plan Workbook, fact sheet 95-089

${ }^{6}$ Hart, R. (2001). Plant biodiversity on shortgrass steppe after 55 years of zero, light, moderate or heavy cattle grazing. Plant Ecology, 155: 111-118; Jackson, R., Banner, J., Jobbágy, E., Pockman, W. \& Wall, D. (2002). Ecosystem carbon loss with woody plant invasion of grasslands. Nature, 418: 623-626.

${ }^{7}$ Farley, J. Schmitt F., A. Alvez, J. Ribeiro de Freitas Jr., N. (2012). How valuing nature can transform agriculture. Solutions, 2(6): 64-73. http://www.thesolutionsjournal.com/node/1014 Citation on p. 64.

8 ibid. p. 64
} 
The transformative benefits of grassland grazing have been brought to a huge audience of millions through Allan Savory's dramatic presentations on TED.com and YouTube, and through his book, The Grazing Revolution. He refers to "holistic planned grazing” as a method of livestock management that can rescue over a billion hectares of grasslands from corn and soy crops intended for livestock in factory farms. That system, Savory charges, erodes fully ten tonnes of soil per person on the planet, an altogether unsavory and unsustainable level of land exploitation. ${ }^{9}$ It might be that Savory's international efforts can highlight the local work of individuals such as Gilvesy.

New grassland grazing techniques have much in common with the species of design innovations referred to as "bio-mimicry." 10 The idea behind bio-mimicry is to design systems and products that adapt the elegance of Nature's patterns, time-tested forms of research and development that have taken place during billennia of evolution. In grasslands, natural systems balance the exchange of gases between soil and air to the benefit of soil, plants, animals, and atmosphere. The Marin County technique of composting manure on cattle-grazing land is referred to as "carbon farming," because it engages farmers in adapting that ancient exchange to boost the storage of carbon and growth of plants, drawing down carbon dioxide from the air to serve as soil-based carbon that feeds plants. By mimicking Nature, these ranchers do deliberately what Nature does without thinking: deliver ecoservices that can keep carbon in the soil and out of the atmosphere, where its imbalance threatens havoc in global climate systems.

\section{To bee or not to bee}

Anyone who has toured Gilvesy's land over the last four years has enjoyed watching him get overtaken by his enthusiasm for the pollinators making their homes in tree stumps he has prepared just for them. "I'm the king of the wild bees," he sometimes says. I call him the wasp whisperer.

The worrisome decline of bees has attracted considerable public attention over the last several years. Bees are an iconic species, and likely the only insects to enjoy charismatic status ranking with elk, polar bears, and grizzlies, even though their bite is worse than their buzz. Bumble bees are commonly equated with pollination, and anyone assessing the impact of the disappearance of bees quickly understands that this could have staggering economic impact on fruit, vegetable, edible oil, coffee, and cacao crops. I find it mildly amusing that journalistic reports on the economic damage that would be wreaked by loss of pollination services outweighs coverage of the likely impacts leading to malnutrition, famine, and death. But then, who am I to complain when people start to attach economic value to ecosystem services? One careful study from 2008 estimated the economic losses following collapse of natural pollinators at \$217 billion

\footnotetext{
${ }^{9}$ Nierenberg, D. (2014, January). Healing the land, grazing for solutions. FoodTank.

${ }^{10}$ Benyus, J. (2002). Biomimicry: Innovations inspired by nature. New York: Harper Collins.
} 
U.S. per year. ${ }^{11}$ I don’t imagine many private investors would balk at paying a few billion a year to avoid the collapse of essential corporate infrastructure. However, it appears that using public money to pay for the work needed to produce environmental services is considered a more painful loss than $\$ 217$ billion a year.

But Gilvesy is more innovative than I am when it comes to such matters. He figured out two things that I missed. First, he recognized that wild pollinators are better pollinators than the bees Europeans brought over to North America. He gave most of his attention to supporting indigenous and wild varieties of pollinators on his land. As it turns out, scientific studies confirm that wild pollinators are about twice as effective as domesticated ones, probably because they come in a variety of shapes and sizes, and so can be more effective pollinating the multiple varieties of grassland flowers. ${ }^{12}$ Reviewing the evidence on yields in a scientific paper, The Economist — no slouch when it comes to valuing filthy lucre-headlined that "variety is the spice of life." 13 That's a nice admission for The Economist to make. Free ecosystem services, it seems, can outperform human-made ones. Who knew?

Perhaps illustrating the kind of deeply intuitive and experiential knowledge possessed by peasants and farmers, albeit seldom respected by formally credentialed scientific practitioners, ${ }^{14}$ Gilvesy instinctively grasped the business lesson taught by pollinating freeloaders trespassing on his property. He sets aside between four and seven percent of his land for wilderness, precisely for purposes such as maintaining habitat for pollinators. No big deal, some would say: that land is not productive anyway. Productive and unproductive have become fighting words for Gilvesy. "The metrics are wrong. It is productive because it slows hot, drying winds and because it hosts pollinators," he says. He takes the same view to what some might describe as his "unproductive" use of time taking vegetarians and vegans on tours of his ranch. "Whether you love us for our beef, or love us for our bees, we don't care.” If vegans pay taxes that go to ecosystem services, they're as much his customer base as carnivores.

The dated, narrowly human-centered and arbitrary division between productive and unproductive reveals the mindset of those who believe progress must be wrested from Nature, and that consequently all subsidies for agriculture should support domestication and subjugation of Nature. In the future, students will learn about how government and university agriculture departments once thought this way, just as centuries before the leading astronomical thinkers thought the world was flat and the earth was the center of the universe. Old ideas die very slowly, it seems.

\footnotetext{
${ }^{11}$ Helmholtz Association of German Research Centres. (2008, September 15). Economic value of insect pollination worldwide estimated at U.S. \$217 Billion. ScienceDaily. Retrieved November 22, 2014 from www.sciencedaily.com/releases/2008/09/080915122725.htm

${ }^{12}$ Garibaldi, L. et al. (2013). Wild pollinators enhance fruit set of crops regardless of honey bee abundance. Science, 339: 1608-1611.

${ }^{13}$ Variety is the spice of life. (2013, March 2). The Economist.

${ }^{14}$ McIntyre, B., Herren, H., Wakhungu, J., \& Watson R. (eds.). (2009). Agriculture at a Crossroads. International Assessment of Agricultural Knowledge, Science and Technology for Development. Washington: Island Press.
} 